\title{
Review
}

\section{Role of Hypoxia in the Control of the Cell Cycle}

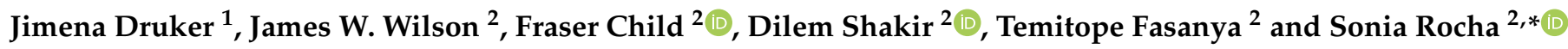 \\ 1 Centre for Gene Regulation and Expression, School of Life Sciences, University of Dundee, \\ Dundee DD1 5EH, UK; j.druker@dundee.ac.uk \\ 2 Department of Molecular Physiology and Cell Signalling, Institute of Systems, Molecular and Integrative \\ Biology, University of Liverpool, Liverpool L69 7ZB, UK; James.Wilson3@liverpool.ac.uk (J.W.W.); \\ F.Child@liverpool.ac.uk (F.C.); Dilem.Shakir@liverpool.ac.uk (D.S.); Temitope.Fasanya@liverpool.ac.uk (T.F.) \\ * Correspondence: srocha@liverpool.ac.uk; Tel.: +44-(0)151-794-9084
}

Citation: Druker, J.; Wilson, J.W.; Child, F.; Shakir, D.; Fasanya, T.; Rocha, S. Role of Hypoxia in the Control of the Cell Cycle. Int. J. Mol. Sci. 2021, 22, 4874. https://doi.org/ $10.3390 /$ ijms 22094874

Academic Editor: Nam Deuk Kim

Received: 13 April 2021

Accepted: 3 May 2021

Published: 5 May 2021

Publisher's Note: MDPI stays neutral with regard to jurisdictional claims in published maps and institutional affiliations.

Copyright: (c) 2021 by the authors. Licensee MDPI, Basel, Switzerland. This article is an open access article distributed under the terms and conditions of the Creative Commons Attribution (CC BY) license (https:/ / creativecommons.org/licenses/by/ $4.0 /)$.

\begin{abstract}
The cell cycle is an important cellular process whereby the cell attempts to replicate its genome in an error-free manner. As such, mechanisms must exist for the cell cycle to respond to stress signals such as those elicited by hypoxia or reduced oxygen availability. This review focuses on the role of transcriptional and post-transcriptional mechanisms initiated in hypoxia that interface with cell cycle control. In addition, we discuss how the cell cycle can alter the hypoxia response. Overall, the cellular response to hypoxia and the cell cycle are linked through a variety of mechanisms, allowing cells to respond to hypoxia in a manner that ensures survival and minimal errors throughout cell division.
\end{abstract}

Keywords: hypoxia; cell cycle; HIF; PHDs; 2-OGDs; mitosis

\section{Introduction}

The cell cycle is a process through which cells faithfully replicate their genetic material. Strict control over its progression is therefore needed to avoid errors that could result in cell death or cell malignancy. As such, understanding how the cell cycle is affected by external and internal stresses is of the utmost importance, in particular, the stress caused by hypoxia, or reduced oxygen availability. Hypoxia is an important factor in embryo development, but is also present in numerous pathological settings such as ischaemic events and cancer [1]. Oxygen is fundamental for both energy homeostasis and cellular viability, therefore, to deal with such stresses, cells possess complex response mechanisms that aim at restoring oxygen homeostasis. In this review, we highlight how hypoxia sensing and signalling pathways interface with the cell cycle, in addition to how the cell cycle affects the hypoxia sensing and response components in mammalian cells.

\section{Hypoxia Signalling Pathway}

In cells, oxygen is sensed by a class of 2-oxoglutarate, iron-dependent dioxygenases (2-OGD); the most recognized of which are the prolyl-hydroxylases (PHDs). These are instrumental in the signalling cascade initiated in response to a reduction in oxygen, which ultimately results in the activation of the hypoxia-inducible factor (HIF) transcription factor family. HIFs are heterodimers corresponding to a HIF- $\alpha$ (alpha) and HIF-1 $\beta$ (beta) subunit [2], while the PHDs present three isoforms (PHD1, PHD2, and PHD3) and possess a low affinity for oxygen so that any small deviation from normal oxygen concentrations will result in their enzymatic inactivation [3]. Under normal oxygen concentrations, the PHDs hydroxylate specific proline residues in the oxygen-dependent degradation domain (ODD) of HIF- $\alpha$. This post-translational modification increases the binding affinity of the von Hippel-Lindau (VHL) protein, which acts as part of the recognition complex for the E3 ligase comprising of Elongin B/C, Cullin2, and RBX1 [4]. This complex ubiquitinates HIF- $\alpha$, which marks the protein for proteasomal degradation. In the absence of either oxygen, iron $\left(\mathrm{Fe}^{2+}\right)$, or 2-oxoglutarate (2-OG), the PHDs cannot function and the ability 
of VHL to promote ubiquitination of HIF is reduced, which results in the stabilization of HIF- $\alpha$. Upon stabilization, and in combination with its binding partner HIF- $1 \beta$, a HIF- $1 \alpha-\beta$ heterodimer promotes the transactivation of a variety of target genes in response to reduced oxygen concentrations (for a recent review on HIF-dependent genes see [5]). Notably, it is important to highlight that, in addition to HIF, further transcription factors are also activated by hypoxia. These include Myc, p53, AP-1, Sp1, and NF-kB [6] (Figure 1).

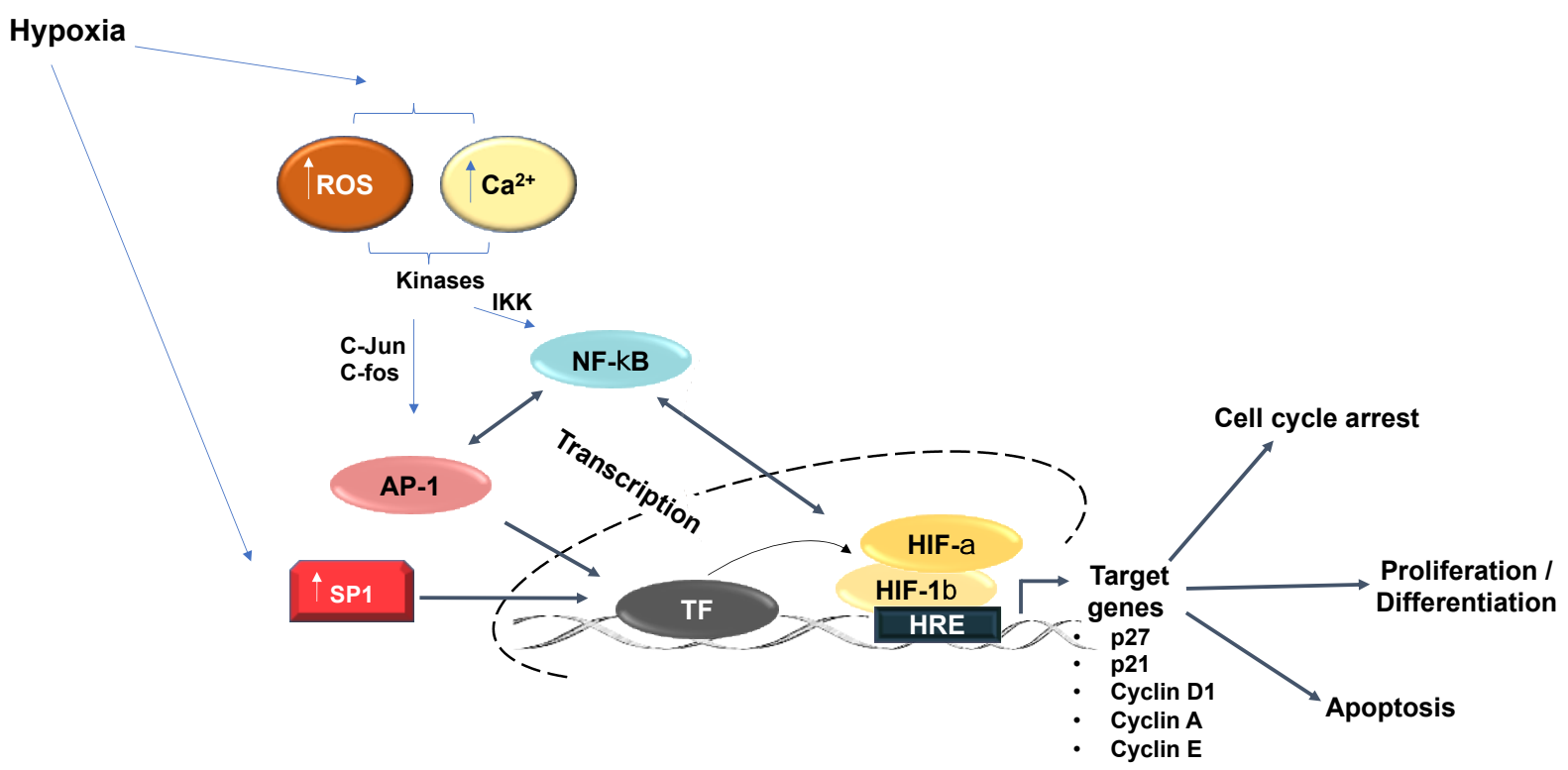

Figure 1. Hypoxia-relevant transcription factor crosstalk. Additional transcription factors than HIF regulate the hypoxia response. Hypoxia increases SP1 expression, which increases SP1 binding to gene promoters and upregulated transcriptional activation of downstream targets. Hypoxia further promotes increased SP1 binding to an upstream GC Box to augment the hypoxia-response element-dependent downstream gene activation. Hypoxia induces AP-1 activity. Mitogen-activated protein kinases (MAPK) activate AP-1 subunits (c-jun/c-fos) in response to hypoxia. Activation of AP-1 heterodimers predominantly exert their effects in cooperation with additional transcription factors including NFKB and HIF- $1 \alpha$ to activate common target genes including regulation of cell proliferation and apoptosis. NFkB likewise regulates HIF-1 $\alpha$ transcription.

Additional important 2-OGD enzymes, with links to hypoxia sensing and response, are JmjC-histone demethylases and TET DNA demethylases. Moreover, other JmjChydroxylases and RNA demethylases such as FTO and ALKBH5 are likewise potential contributors to the hypoxia response. However, additional work is needed to identify their true involvement. Interestingly, all of these aforementioned enzymes also have the potential to either directly or indirectly interface with the cell cycle (Figure 1).

\section{Cell Cycle Overview}

The cell cycle can be divided into two main stages: interphase and cell division (Figure 2). Interphase is where cells spend the majority of the time and can be subdivided into Gap1 (G1), S (DNA synthesis), and Gap2 (G2) phases; whereby following the G2-phase the cells enter mitosis (M) (cell division). Here, the duplicated DNA is distributed equally into two daughter cells, which then enter a new cell cycle (Figure 2). In G1, individual cells grow and their cellular content is duplicated, while in S-phase, the DNA is replicated, then in G2, the cell undergoes further growth and prepares for cellular division [7]. Finally, in mitosis, the cell divides its contents into two equal daughter cells. Here, depending on the cell type, cells will either enter another G1 stage or enter quiescence (also known as G0), whereby the cell exits the cell cycle and stops dividing [8]. 


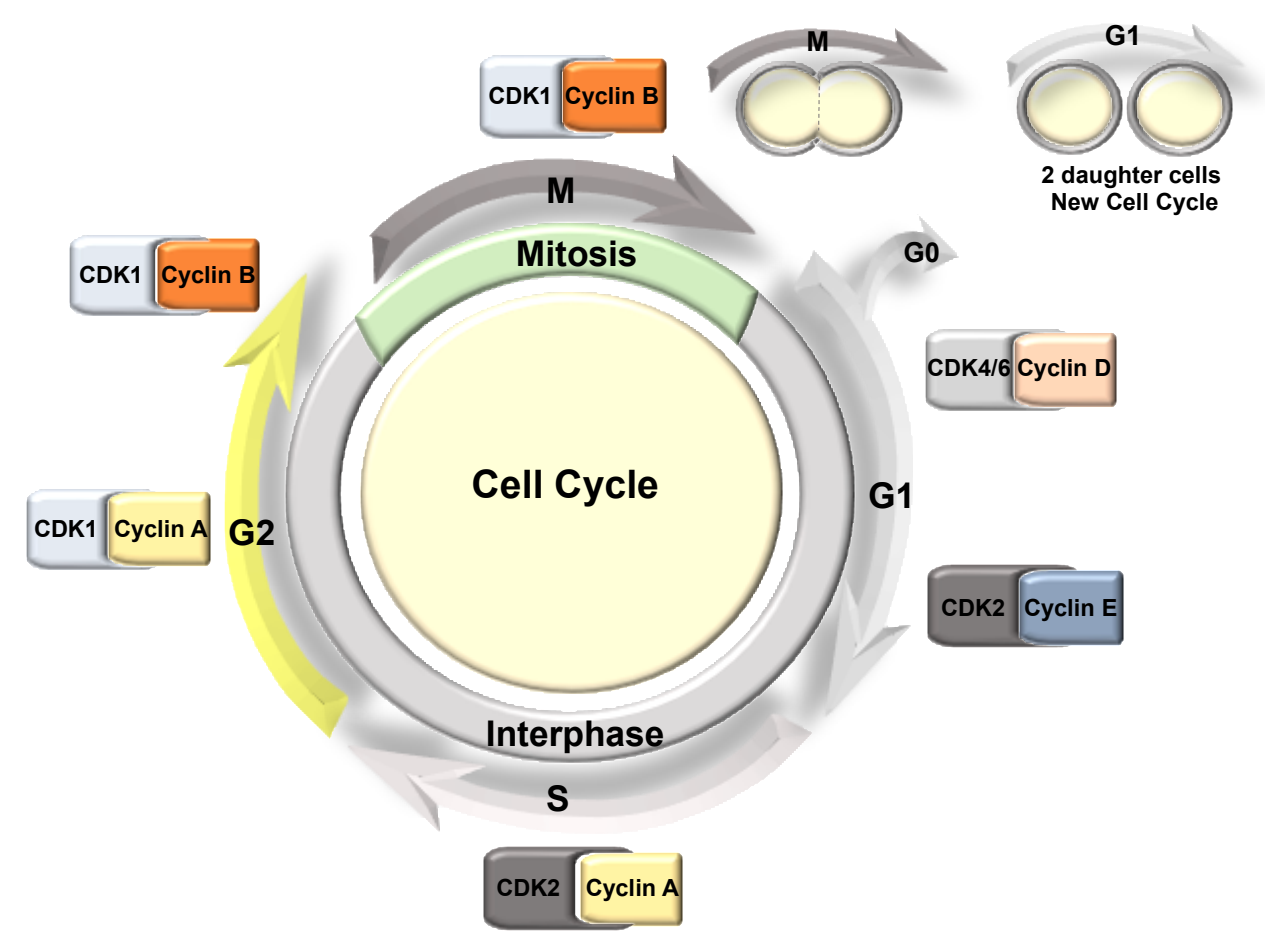

Figure 2. The mammalian cell cycle phases. The cell cycle is divided into two main phases: interphase that includes G1, S, and G2, and mitosis. Each of these stages is associated with a CDK/Cyclin pair, controlling the progression of the cell cycle.

The progression through the cell cycle is regulated by serine/threonine protein kinases known as cyclin-dependent kinases (CDKs), alongside their partner proteins, cyclins (Figure 2). However, CDK-independent roles have also been described for the cyclins in the regulation of apoptosis, differentiation, DNA repair, and metabolism reviewed in $[9,10]$. CDK-cyclin complexes phosphorylate specific substrates in each phase of the cell cycle, driving the transition to the next phase. The activation of the CDK depends on the association with the corresponding regulatory cyclin; therefore, the levels of each cyclin fluctuate during the cell cycle. This oscillation of the cyclin levels is regulated through their targeted degradation by different E3 ligase complexes in response to signalling pathways such as growth factor and oncogene activation [11]. CDK activity is also regulated by phosphorylation and by association with CDK-cyclin inhibitors such as p21 and p27, while the dysregulation of CDK activity is a common feature in many cancers [12,13].

Cell cycle progression is therefore a tightly regulated process that includes several checkpoints that are imperative during cell division to ensure the correct segregation of the genetic material between daughter cells. Furthermore, as the cell cycle is also a highly demanding and energy-consuming process, it follows that the oxygen-sensing system can directly impact cell cycle progression [14]. Indeed, key players in the hypoxia response are involved in the regulation of essential components during each phase of the cell cycle, at each of the transcriptional and protein stability levels, alongside localization and/or activity. Hence, oxygen deprivation or hypoxia must impact normal cell cycle progression [14]. In this review, we provide examples of how cell cycle progression in normal and cancer cells can be affected in response to oxygen levels, focusing on the molecular interplay between hypoxia and known cell cycle regulators.

\section{Hypoxia Mediated Transcriptional Effects on Cell Cycle Components}

Hypoxia plays a central role in diverse aspects of cancer biology as a hypoxic microenvironment is prevalent in solid tumours. It is known that oxygen levels regulate cell proliferation and that depending on the cell type, hypoxia can inhibit cell proliferation by inducing cell cycle arrest [15-17]. However, tumour cells often adapt to survive in 
such hypoxic conditions. This adaptation is partially promoted by the essential role HIF plays in the transcriptional regulation of genes associated with angiogenesis, apoptosis, cell proliferation, and energy metabolism [2]. HIF-dependent activation of these genes provides tumour cells with an adaptive advantage over normal cells during periods of hypoxic stress.

The Myc transcription factor, which is also associated with cell proliferation, is similarly overexpressed in various cancer types [18]. Myc is known to repress the expression of the CDK cyclin inhibitors p21 and p27 [18]. In hypoxia, the expression of p21 and p27 is induced in a HIF- $1 \alpha$ dependent manner, partially by displacing Myc from their promoters [15]. Interestingly, HIF-2 $\alpha$ cooperates with Myc and promotes cell proliferation in renal clear cell carcinomas (RCC) and other cell types [19]. In RCC, HIF- $2 \alpha$ is also known to induce Cyclin D1 via its binding to an enhancer site [20] (Figure 3). The effects of HIF-2 $\alpha$ on cell cycle control in RCC cells have become even clearer following data derived from treatments with a specific HIF-2 $\alpha$ inhibitor (PT2399), in which the cell cycle was identified as the main signature controlled by HIF- $2 \alpha[21,22]$.

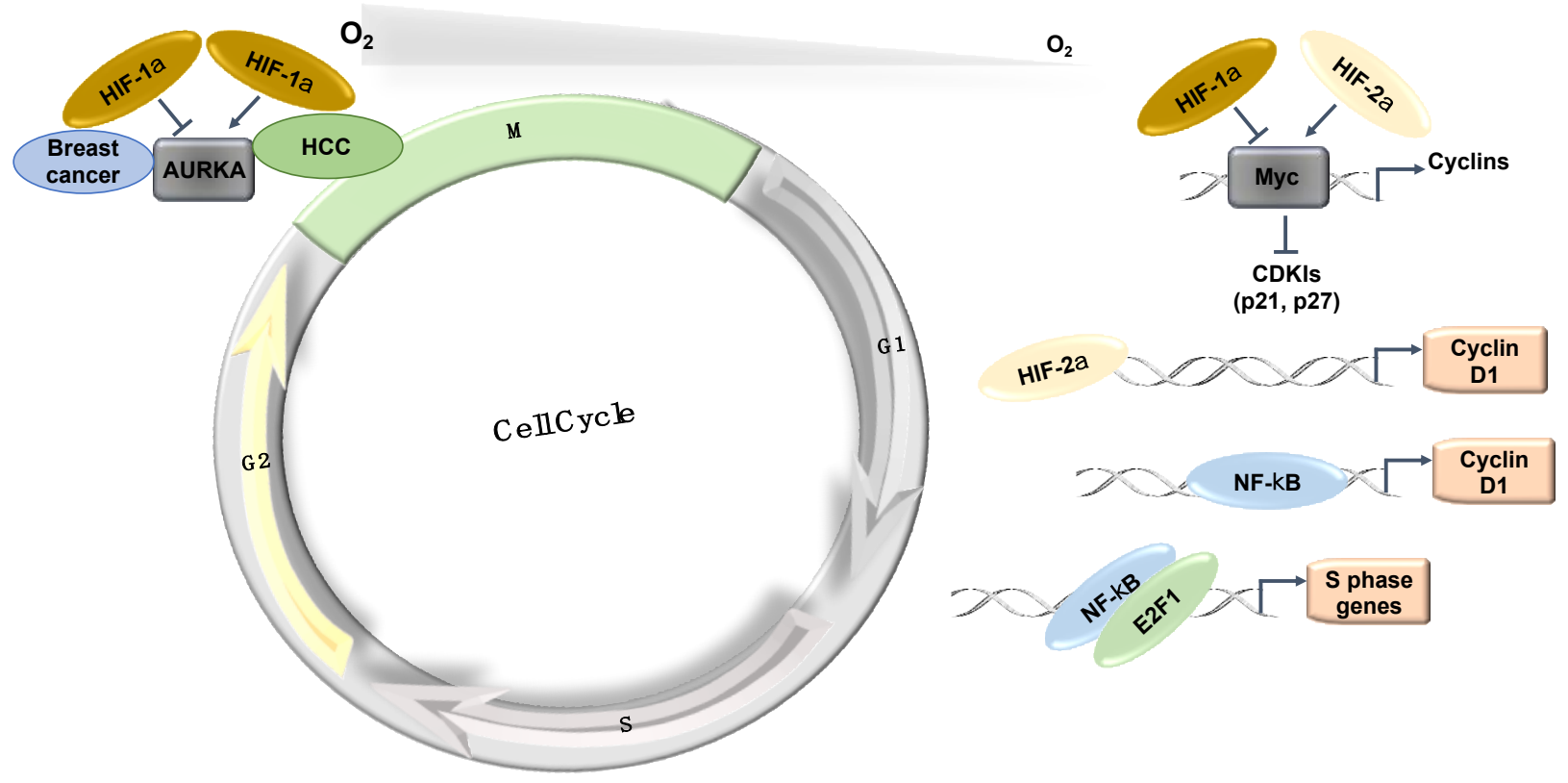

Figure 3. Hypoxia-induced transcriptional effects on the cell cycle. HIFs and NF-kB control the expression of a number of important components of the cell cycle machinery and control mechanisms. HCC: Hepatocellular carcinoma.

The mitotic kinase-Aurora A (AURKA)—also has an important role in mitotic progression and has been related to oncogenic phenotypes [23]. AURKA is overexpressed in a variety of different tumours and has been implicated in cell transformation and centrosome amplification [24,25]. In hepatocellular carcinomas (HCC), the increased levels of AURKA do not always correlate with gene amplification [26]. Interestingly, AURKA was shown to be induced by hypoxia in a HIF-1 $\alpha$ dependent manner in HepG2 cells [27] as HIF- $1 \alpha$ binds to the AURKA promoter and upregulates its transcription, leading to an increase in cell proliferation [27]. This study proposed that AURKA might be involved in the hypoxia-induced proliferation of HCC tumours [27] (Figure 3). In this tumour type, hypoxia induction of HIF- $1 \alpha$ and AURKA might be involved in promoting HCC proliferation [27]. However, in breast cancer cells (MCF-7, MDA-MB-231, and SK-Br3), microarray analysis in response to hypoxia illustrates that hypoxia downregulates AURKA [28]. In this study, the authors demonstrated that hypoxia downregulated AURKA via a HIF- $1 \alpha$ dependent mechanism, suggesting that HIF- $1 \alpha$ is a negative regulator of AURKA in breast cancer tumours [28]. These studies highlight the cell-specific nature of HIF's function in cell cycle regulation. 
Cell division cycle-associated protein 2 (CDCA2) has similarly been shown to be a target of the hypoxia pathway [29]. Analyses of publicly available ChIP-Seq and RNA-Seq datasets demonstrate that CDCA2 is induced in hypoxia and is important for the control of proliferation in prostate cancer cells. The intracellular signal transducer protein, SMAD3, binds to the CDCA2 promoter and recruits HIF- $1 \alpha$. HIF- $1 \alpha /$ SMAD3 then mediates the transcriptional regulation of CDCA2 in hypoxic tumours, leading to cancer cell proliferation [29].

HIF's control of the cell cycle is also mediated by its ability to induce a variety of microRNAs and long non-coding RNAs; this aspect was reviewed in $[14,30]$.

Among all known hypoxia-stimulated transcription factors, the importance of NF- $\mathrm{kB}$ has been identified in a wide range of signalling systems, alongside its association with many different diseases. In contrast to its well-established role in immune and inflammatory responses, NF- $\mathrm{KB}$ activity is also involved in apoptosis, carcinogenic transformation, and cell cycle transition [31]. The NF- $\mathrm{KB}$ family consists of five distinct members, which include RelA (p65), RelB, c-Rel, NF-kB1 (p105/p50), and NF-kB2 (p100/p52), all of which share a conserved Rel homology domain [31]. Hypoxia activation of NF- $\mathrm{kB}$ occurs via several mechanisms, although some of the details still require further investigation. Hypoxia has been shown to control NF- $\mathrm{KB}$ via the action of PHDs and FIH [32-34], and requires the involvement of calcium/calmodulin-dependent kinase II (CAMKII), transforming growth factor kinase 1 (TAK1) and IKB kinase (IKK) [35-37].

$\mathrm{NF}-\mathrm{kB}$ has several target genes identified with a role in cell cycle progression (reviewed in detail [31]). Ultimately, cyclin D1 provides a predominant link between NF- $\kappa B$ and cell cycle progression (Figure 3). Cyclin D1, in association with CDK4 and CDK6, promotes G1/S phase transition through CDK-dependent phosphorylation of retinoblastoma protein $(\mathrm{pRB})$ [38]. This phosphorylation event releases the transcription factor E2F, which is required for the activation of S-phase-specific genes, although several studies have conversely reported that NF- $\mathrm{KB}$ can itself induce cell cycle arrest [39]. Overexpression of RelA has been shown to arrest cells at G1/S-phase transition [40]. c-Rel overexpression leads to cell cycle arrest through p53 protein stabilization, an important upstream activator of the CDK-inhibitor, p21 [41]. Additionally, p21 expression can be further increased by the Formin-2 (FMN2) protein, which is a component in the p14ARF tumour suppressor pathway [42]. In this study, FMN2 was shown to increase with hypoxia stimulation via an NF- $k B$-dependent mechanism [42]. Moreover, several additional studies have shown that NF- $\kappa B$ can be activated by a hypoxic environment $[35,36,43,44]$.

Finally, a physical and functional interaction exists between the IKK/NF- $\mathrm{KB}$ signalling pathway and the cell cycle regulatory proteins of the E2F family that controls S-phase entry, which suggests that NF- $\mathrm{KB}$ plays a functional role in controlling cell division $[45,46]$. Indeed, direct phosphorylation of E2F by IKK $\alpha$ and IKK $\beta$ resulted in the nuclear accumulation and enhanced DNA binding of the E2F4/p130 repressor complex, which led to the suppression of E2F-responsive gene expression [45]. In contrast, E2F1 and NF- $\mathrm{kB}$ interactions were shown to control the timing of cell proliferation [46] (Figure 3). Despite all of these links between NF- $\mathrm{KB}$ and cell cycle regulation, a more systematic and mechanistic analysis of how NF- $\mathrm{kB}$ controls the cell cycle in hypoxia is needed.

\section{Hypoxia Transcriptional-Independent Effects on Cell Cycle Components}

Apart from transcription, hypoxia can alter a variety of other processes such as translation and post-translational modifications. As such, non-transcriptional mechanisms are also involved in hypoxia-induced cell cycle alterations (Figure 4). 


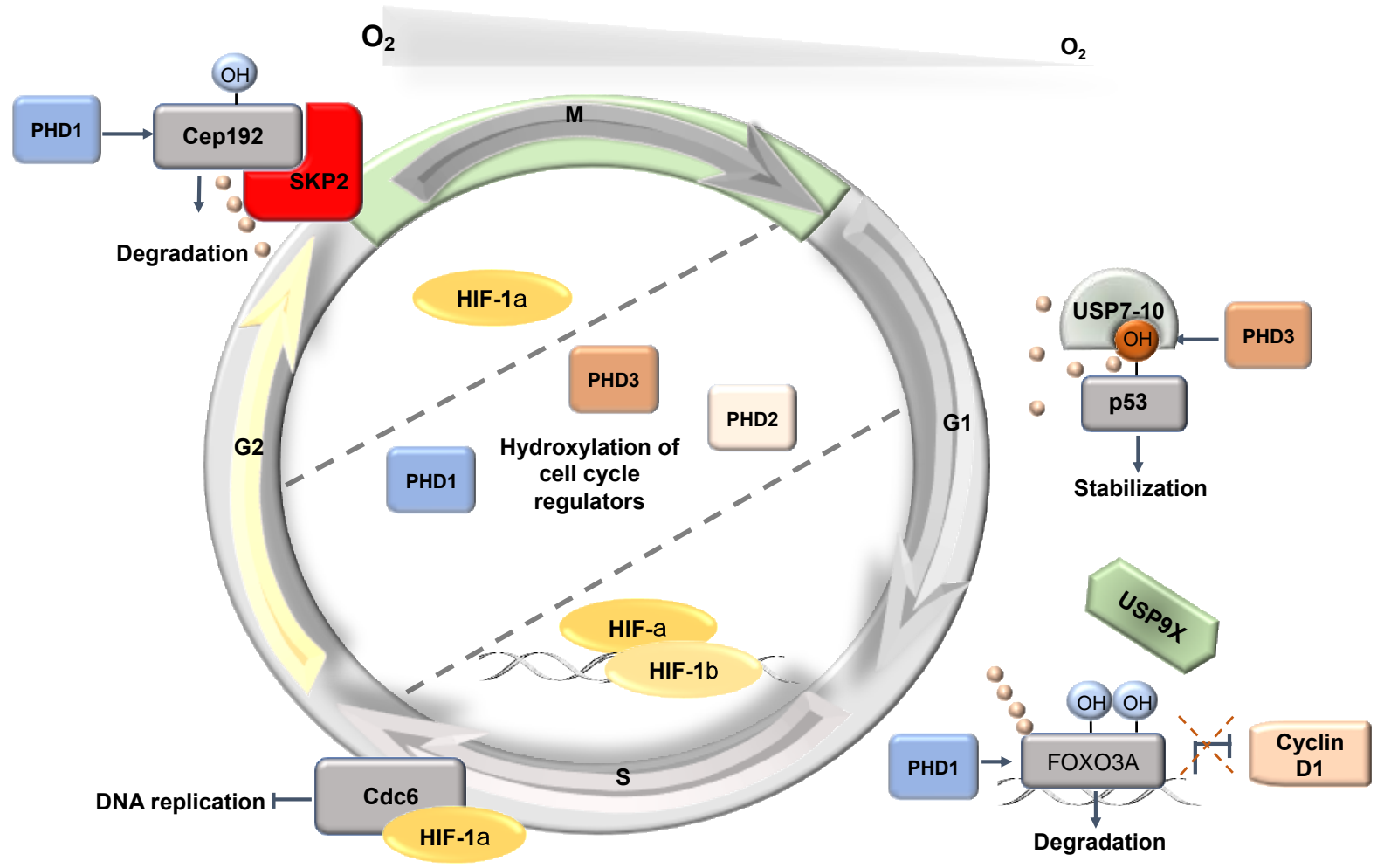

Figure 4. Hypoxia-induced post-transcriptional effects on the cell cycle. HIF has a non-transcriptional effect controlling DNA replication. In addition, PHD1 and PHD3 have non-HIF targets involved in the control of the cell cycle.

\subsection{Non-Transcriptional Role for HIF-1 $\alpha$}

A non-transcriptional mechanism through which cell cycle progression is inhibited involves HIF- $1 \alpha$ regulation of DNA helicase loading. During G1, under normal conditions, the MCM proteins assemble into a hexamer, poised in an inactive yet loaded state, by both Cdc6 and Cdt1 [47]. When transitioning from G1 into the S-phase, CDK2 catalyses the phosphorylation of the complex and promotes the nuclear export of the inhibitory Cdc6, therefore allowing for Cdc7-mediated phosphorylation of the MCM complex and the subsequent activation of DNA replication [48,49]. Upon hypoxic stress, HIF-1 $\alpha$ interacts with Cdc6 to promote nuclear localization with the MCM complex [50]; while HIF- $1 \alpha$-bound Cdc6 increases MCM association with chromatin, the presence of HIF- $1 \alpha$ prevents Cdc7 from phosphorylating the complex [51]. Consequently, replication origin firing is blocked as Cdc45 and DNA polymerase $\alpha$ cannot be recruited. Subsequently, HIF-dependent blocking of DNA replication and proliferation was observed across a variety of cell types including, cancer cell lines, haematopoietic stem cells, fibroblasts, and lymphocytes [51-53]. While the regulatory binding of HIF- $1 \alpha$ to protein complexes inhibits the proliferative signals in some tissues, several cancer cells possess the capacity to proliferate even under hypoxic conditions [54].

\subsection{HIF-Independent PHD-Dependent Roles in Cell Cycle}

Given that oxygen is sensed by the 2-OGDs, it is likely that other aspects of the cell cycle could be regulated independently of HIF activity. This is definitely the case for the PHDs, whose association to cell cycle control has been best documented [14]. Of note, in addition to requiring oxygen as a co-substrate, their functional catalytic activity further requires the presence of additional co-factors: 2-oxoglutarate and iron [55,56]. PHDs can additionally monitor amino acid concentrations [57], cellular nutrients [58], and act as metabolic sensors to detect defects in metabolic pathways such as the tricarboxylic acid (TCA) cycle [59]. As such, PHD activity is similarly inhibited following an accumulation of metabolite intermediates due to mutations in the metabolic enzymes: fumarate hydratase 
(FH), succinate dehydrogenase (SDH), and isocitrate dehydrogenase 1 and 2 (IDH1 and IDH2) [60].

Whilst still controversial within the hypoxia field [61,62], over the last decade, emerging studies have highlighted alternative roles for PHDs, identifying substrates, in addition to HIF- $\alpha$, which are involved in a myriad of different pathways and regulated through PHD-hydroxylation [3].

Interestingly, within these emerging substrates, both PHD1 and PHD3 have been shown to play critical roles in response to oxygen depletion: first, in the regulation of proteins involved in the DNA damage response, and second, in centrosome biogenesis $[63,64]$. These two processes are critical in regulating the cell cycle. In cultured human cells, Moser et al. (2013) showed that variations in oxygen concentration altered the mitotic cell cycle progression through PHD1-mediated hydroxylation of the centrosomal protein 192 (Cep192) [63]. Cep192 acts as a large scaffold protein in human centrosomes and its expression is required for centrosomal duplication and maturation in addition to centriole duplication [65-67]. The authors discovered that after two and four hours in $1 \% \mathrm{O}_{2}$, the protein levels of Cep192 stabilised to those comparable to HIF-1 $\alpha$ in U2OS cells. Cep192 undergoes a post-translational modification, whereby in normoxia, PHD1 hydroxylates proline 1717, which promotes Cep192 proteasomal degradation. However, unlike HIF- $\alpha$, which is degraded through the VHL pathway, PHD1-mediated hydroxylation of Cep192 stimulates the recruitment of the SCF(Skp2) E3-ligase complex, which mediates the ubiquitination that promotes Cep192 proteasomal degradation. The study by Moser et al. (2013) ultimately provided a mechanistic link between PHD activity and the direct regulation of the cell cycle, highlighting the role that oxygen availability plays on the processes of centrosome duplication and maturation, in addition to centriole duplication through the modulation of Cep192 stability.

Alongside Cep192, PHD1 has likewise been shown to modulate protein levels of the G1 cyclin - cyclin D1 [68]. Targeted-hydroxylation of the Forkhead Box O3A (FOXO3A) transcription factor at proline residues 426 and 437 in normoxia was revealed to destabilise its interaction with the deubiquitinase USP9x and promote FOXO3a degradation, a process that leads to an accumulation of cyclin D1 [68]. Moreover, PHD1 regulation of cyclin D1 has further been demonstrated in breast cancer cells [69], whereupon inactivation of the Egln2 (Phd1) gene, cyclin D1 levels, and mammary gland cell proliferation decreased.

Interestingly, it is not solely PHD1 that has been found to be involved in the regulation of cell cycle components. However, while PHD2 represents the most abundant PHD isoform, it has currently not been shown to interact with any validated cell cycle machinery components. However, as the predominant regulator in the hypoxia pathway, many studies have focused on the role PHD2 plays in various tumour types. Percy et al. (2006) proposed that PHD2 functions as a tumour suppressor [70]. Tao et al. (2016) revealed that PHD2 inhibited cell proliferation due to cell cycle arrest at the G1/S-phase transition [71]. Additionally, the authors demonstrated that the arrest in the cell cycle was facilitated by negative regulation of cyclin D1 in a PHD2 hydroxylation-dependent manner [71]. These findings correlate with previously published data indicating that PHD2 can act in a tumour suppressor role in cancer cells [72-74]. However, several other studies have shown that downregulation of PHD2 in tumour cells corresponds to a reduction in tumour growth $[75,76]$. This indicates that PHD2 can act as a tumour promoter or tumour suppressor, depending on cell and/or tissue type.

PHD3 has similarly been suggested to function as a tumour suppressor, whereby its expression induced apoptosis [77] and inhibited angiogenesis and tumour growth [78]. Equally, PHD3 is required to induce apoptosis and inhibit tumour growth in vivo [79]. Moreover, cell cycle distribution analysis revealed that the overexpression of PHD3, in conjunction with radiation in pancreatic cancer cells, results in a reduced S-phase and a lengthened G2/M phase [80].

p53 has an important role in cancer biology as an important regulator of the cell cycle and it is also activated in hypoxia [81]. PHD3 regulates p53 stability by hydroxylation 
at proline 359 [82]. This modification increases p53 association with USP7 and USP10 deubiquitinases, leading to reduced ubiquitination and enhanced stabilisation [82].

\subsection{Hydroxylation and Phosphorylation Interplay}

Proline hydroxylation usually acts as a docking site for protein-protein interactions, best exemplified by the HIF-1 $\alpha /$ VHL association [83]. As such, it is possible that apart from ubiquitin ligases, proline hydroxylation could act as a binding site for other proteins including kinases or phosphatases (Figure 5). The AKT kinase is a key player in oncogenesis [84]. Guo et al. (2016) demonstrated that PHD2 mediated hydroxylation of AKT promotes the binding of this kinase to the VHL ubiquitin ligase. Interestingly, this interaction does not target AKT for degradation, but instead leads to AKT inactivation through PP2A phosphatase-mediated dephosphorylation. It was suggested that in hypoxic microenvironments or in cells lacking a functional VHL protein, AKT is hyper-activated, which promotes cancer cell survival [85]. These examples demonstrate that hydroxylation mediated by PHDs not only targets proteins directly for degradation, but also plays an important role in regulating protein-protein interactions.

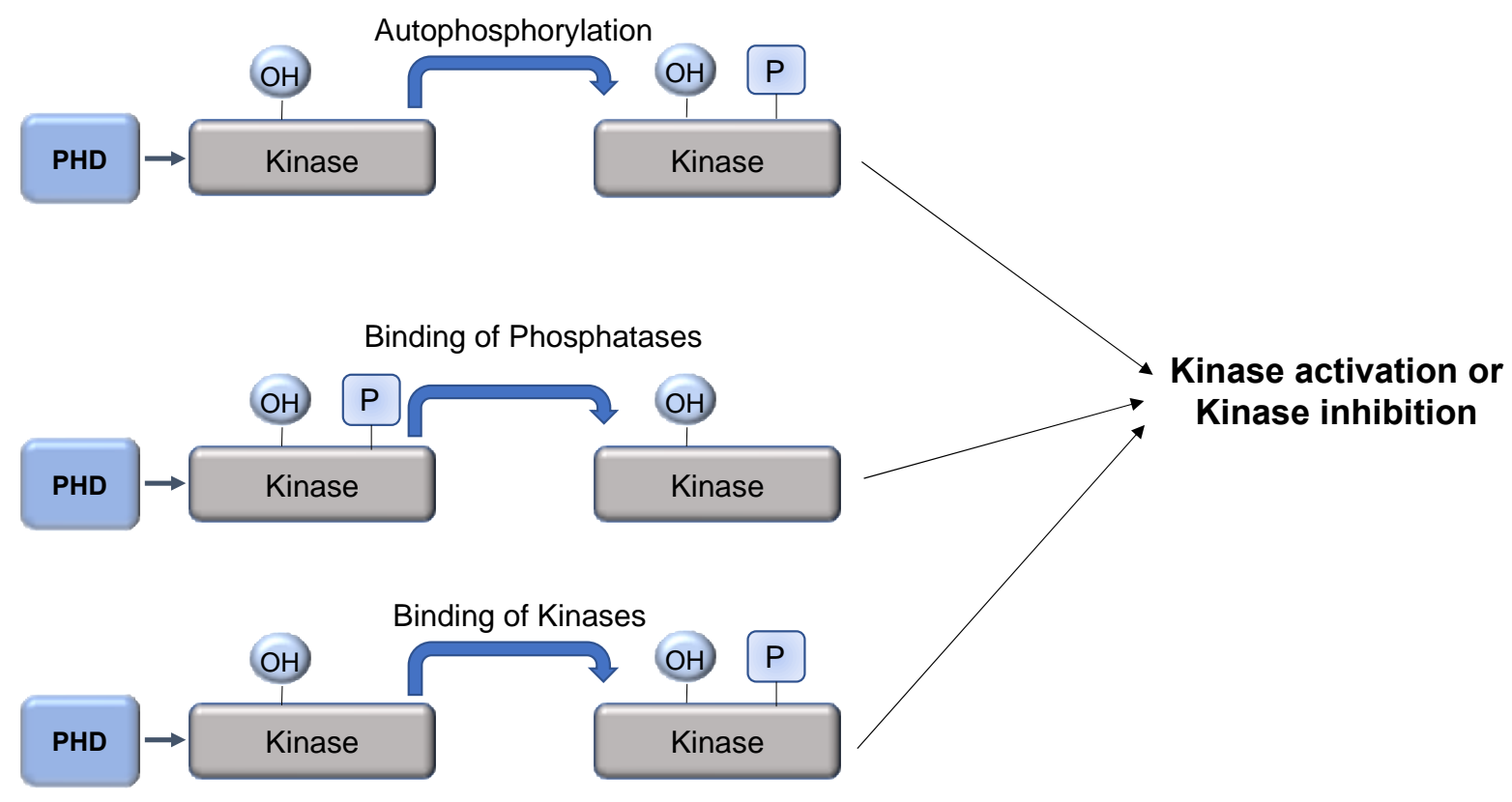

Figure 5. PHD-mediated hydroxylation as a mechanism to regulate kinase activity. Hydroxylation of kinases can lead to induction of autophosphorylation, recruitment of phosphatases, or even other kinases. This will result in changes to kinase activity.

Another such example suggests an interplay between two protein modifications as proline hydroxylation and phosphorylation have been recently reported to play a role in cell cycle progression [86]. In a study of the DYRK1 kinase, a conserved proline located in the kinase domain was shown to be hydroxylated by PHD1 [86]. Autophosphorylation in a specific tyrosine residue is critical for the enzymatic activity of DYRK1. Interestingly, PHD1 mediated hydroxylation of DYRK1 takes place during translation, but before tyrosine phosphorylation occurs. Furthermore, proline hydroxylation is important for the tumour suppression activity of DYRK1 toward the regulation of VHL E3 ligase activity and hence, the stability of VHL substrates critical for cell cycle progression such as HIF-2 $\alpha$, AURKA, and cyclin D1. In conclusion, Lee et al. (2020) showed that DYRK1 hydroxylation precedes the phosphorylation/activation of the kinase, which is required for VHL tumour suppression function [86,87]. Since PHD1 hydroxylates the proline within a conserved kinase domain (CMGC), the authors suggest that proline hydroxylation could be an essential mechanism in the catalytic activation of all eukaryotic CMGC kinases [86]. CMGC kinases 
have crucial roles in controlling the cell cycle and include CDKs, MAPK, and CDK-like kinases [88]. Unbiased proteomic studies are therefore needed to investigate the possibility that proline hydroxylation has a global effect on protein phosphorylation.

\section{How the Cell Cycle Controls the Hypoxia Response}

Since the cell cycle is a highly coordinated process and considering the published links to the regulatory roles of both HIF and the PHDs within the cell cycle, it could be speculated that either HIF and/or the PHDs would themselves be subject to regulatory control by the cell cycle. Indeed, evidence of such control already exists.

\subsection{Cell Cycle Components-Mediated Control of HIFs}

In addition to its regulatory dioxygenases, several kinases directly involved in the cell cycle have similarly been shown to directly phosphorylate and regulate HIF- $\alpha$ [89].

Indeed, CDK1 has been shown to directly phosphorylate HIF- $1 \alpha$ and promote HIF stabilization and activity [90]. Additionally, CDK2 promotes HIF- $1 \alpha$ transactivation domain function, alongside upregulating HIF- $1 \alpha$-mediated expression of downstream target genes [91]. However, the coupling of HIF- $1 \alpha$ to CDK2 presents a dualistic function, whereby CDK2-cyclin E stimulates HIF-1 $\alpha$ degradation through chaperone-mediated autophagy during the G1/S-phase transition. This, in turn, circumvents the inhibitory effects on DNA replication elicited through any HIF- $1 \alpha-\mathrm{MCM}$ interaction. In contrast, CDK1-cyclin B complexes block the lysosomal degradation pathway, a process that promotes HIF- $1 \alpha$ protein stabilisation and target gene activation [91]. Other important cell cycle regulators such as Aurora B and PLK3 have been shown to directly phosphorylate HIF- $1 \alpha[92,93]$. While Aurora B promoted ChIP-dependent degradation of HIF-1 $\alpha$ [92], PLK3 phosphorylation is important for the reduced half-life of HIF-1 $\alpha$ by an unidentified mechanism [93].

\subsection{Cell Cycle Components-Mediated Control of PHDs}

PHD1 activity is similarly the subject of cell cycle regulation by the cyclin-dependent kinases [94]. Ortmann and co-authors (2016) discovered that the serine 130 residue of PHD1 is phosphorylated, but that phosphorylation was dependent upon CDK activity, cell cycle stage, and specific oncogenic signals. The authors explain that phosphorylation was regulated by the activity of the interphase CDKs $(2,4$, and 6$)$, but not CDK1, and by activation of the proto-oncogenes-Myc and E2F1—both known cell cycle regulators [95,96]. Moreover, whilst phosphorylation does not functionally alter PHD1 hydroxylase activity in vitro, it does govern PHD1 target specificity between HIF-1 $\alpha$ and Cep192, whereby phosphorylation increased PHD1 activity toward Cep192 and reduced the interaction with HIF- $1 \alpha$. This study by Ortmann and co-authors, therefore, establishes a mechanistic link between the cell cycle and the regulation of PHD1 activity in cells. Cell cycle mediators such as CDKs can temporally control the activity of PHDs, whereby specific post-translational modifications (PTMs) can alter their target specificity and direct them to precise targets in response to cellular signals [94]. PHD1 has further been shown to undergo phosphorylation in response to JNK2 activation [97]. JNK2 is also a regulator of the cell cycle [98]. Phosphorylation of serine 74 and serine 162 was detected in breast cancer cells by mass spectrometry. This phosphorylation was associated with increased PHD1 activity toward HIF- $1 \alpha$. However, the kinase controlling these modifications was not investigated.

PHD2 is similarly phosphorylated on serine 125 , in normoxia, by the mitogen-activated serine/threonine kinase p70S6K, whereby phosphorylation enhances PHD2-mediated degradation of HIF-1 $\alpha$ [99]. However, in colorectal cancer cells, the PP2A phosphatase and its regulatory subunit B55 $\alpha$ dephosphorylate the serine 125 residue, which reduces PHD2 activity, thereby enhancing HIF- $1 \alpha$ accumulation and ultimately stimulating autophagymediated cell survival [99].

More recently, the anaphase promoting complex (APC) activator CDC20 has been found to mediate the degradation of PHD3 in HCC cells, ultimately increasing the stability and activity of HIF-1 $\alpha$ [100]. 


\section{Conclusions}

As the cell cycle is a process required to replicate the cell's genome faithfully, therefore, it follows that mechanisms are in place to integrate stress signals with the cell cycle machinery (Table 1). In addition, stress pathways such as those induced by hypoxia that control cell cycle processes should also receive input from the components of the cell cycle. Additional studies of how 2-OGD enzymes interface with the cell cycle will expand our knowledge of this important crosstalk between hypoxia and cell cycle signalling pathways.

Table 1. Summary of the interaction between hypoxia and the cell cycle.

\begin{tabular}{|c|}
\hline Cell Cycle Control Mechanisms in Hypoxia \\
\hline Transcriptional effects \\
\hline $\begin{array}{l}\text { Hypoxia induces the activation of several transcription factors: HIFs, Myc, p53, AP-1, SP1 and NFkB are all involved in the } \\
\text { transcriptional regulation of cell cycle genes e.g., p27, p21, cyclin D1, A, E. }\end{array}$ \\
\hline $\begin{array}{l}\text { Myc regulates the expression of cyclins and CDKI. Performs the opposite role of the HIF- } \alpha \text { subunits in Myc } \\
\text { transcriptional regulation. }\end{array}$ \\
\hline HIF-2 $\alpha$ induces cyclin D1 expression. \\
\hline HIF- $1 \alpha$ can both induce or downregulate AURKA expression. \\
\hline HIF-1 $\alpha /$ SMAD3 regulates CDCA2 expression. \\
\hline NFkB regulates cyclin D1 expression. \\
\hline NFkB/E2F1 regulates S-phase genes expression. \\
\hline Transcription-independent effects \\
\hline HIF-1 $\alpha$ interacts with Cdc6, which blocks DNA replication. \\
\hline PHD1 mediated proline hydroxylation regulates Cep192 and FOXO3A stability as well as DYRK1 activity. \\
\hline PHD3 mediated proline hydroxylation regulates p53 stability. \\
\hline PHD2 mediated proline hydroxylation regulates AKT activity. \\
\hline Regulation of HIFs/PHDs by cell cycle components \\
\hline CDK1 phosphorylates HIF- $1 \alpha$ promoting its stabilization and activity. \\
\hline CDK2 regulates HIF- $1 \alpha$ transactivation activity, while CDK2-cyclin E promotes HIF-1 $\alpha$ degradation through autophagy. \\
\hline Aurora B phosphorylates HIF-1 $\alpha$ promoting its degradation. \\
\hline PLK3 phosphorylates HIF- $1 \alpha$ regulating its half-life. \\
\hline CDK2, 4 and 6 phosphorylate PHD1 at serine 130 regulating its target specificity between HIF-1 $\alpha$ and Cep192. \\
\hline JNK2 regulates the phosphorylation of PHD1 serine 74 . \\
\hline $\begin{array}{c}\text { p70S6K phosphorylates PHD2 at serine 125, while is dephosphorylated by the PP2A-B55 } \alpha \text { phosphatase. This phosphorylation } \\
\text { regulates PHD2 activity. }\end{array}$ \\
\hline CDC20 mediates PHD3 degradation, increasing HIF- $1 \alpha$ stability and activity. \\
\hline
\end{tabular}

Author Contributions: Conceptualization, J.D., J.W.W., and S.R.; Writing-original draft preparation, Writing-review and editing, J.D., J.W.W.; F.C.; D.S.; T.F., and S.R.; Funding acquisition, S.R. All authors have read and agreed to the published version of the manuscript.

Funding: This research was funded by Wellcome Trust, grant number 206293/Z/17/Z; a TetFUND (Nigeria) scholarship to T.F.; and the University of Liverpool.

Institutional Review Board Statement: Not applicable.

Informed Consent Statement: Not applicable.

Conflicts of Interest: The authors declare no conflict of interest. The funders had no role in the design of the study; in the collection, analyses, or interpretation of data; in the writing of the manuscript, or in the decision to publish the results. 


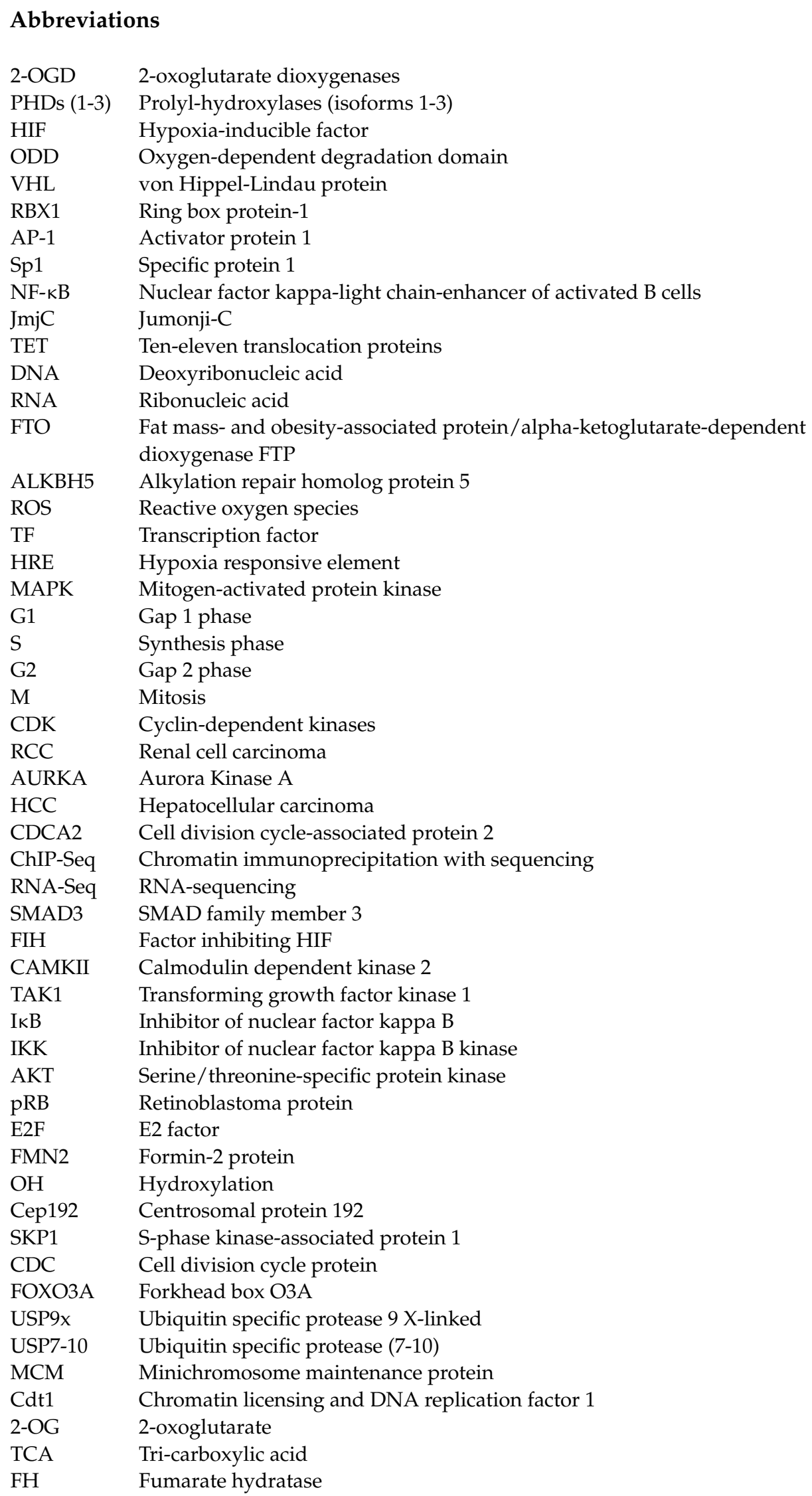




$\begin{array}{ll}\mathrm{SDH} & \text { Succinate dehydrogenase } \\ \mathrm{IDH} & \text { Isocitrate dehydrogenase } \\ \mathrm{O}_{2} & \text { Molecular oxygen } \\ \mathrm{SCF} & \text { Skp-Cullin-F-box containing complex } \\ \text { Egln2 } & \text { Egl-9 family Hypoxia inducible factor } 2 \\ \text { PP2A } & \text { Protein phosphatase } 2 \\ \text { DYRK1 } & \text { Dual-specificity tyrosine phosphorylation-regulated kinase-1 } \\ \text { CMGC } & \text { Cyclin-dependent (CDK), mitogen-activated protein kinase (MAPK), glycogen } \\ & \text { synthase kinases (GSKs) and CDK-like kinases } \\ \text { PLK3 } & \text { Mammalian Polo-like kinase 3 } \\ \text { PTMs } & \text { Post-translational modifications } \\ \text { JNK2 } & \text { c-Jun N-terminal kinase 2 } \\ \text { APC } & \text { Anaphase promoting complex }\end{array}$

\section{References}

1. Mole, D.R.; Ratcliffe, P.J. Cellular oxygen sensing in health and disease. Pediatr. Nephrol. 2008, 23, 681-694. [CrossRef]

2. Rocha, S. Gene regulation under low oxygen: Holding your breath for transcription. Trends Biochem. Sci. 2007, 32, 389-397. [CrossRef]

3. Wilson, J.W.; Shakir, D.; Batie, M.; Frost, M.; Rocha, S. Oxygen-sensing mechanisms in cells. FEBS J. 2020, 287, 3888-3906. [CrossRef] [PubMed]

4. Gossage, L.; Eisen, T.; Maher, E.R. VHL, the story of a tumour suppressor gene. Nat. Rev. Cancer 2015, 15, 55-64. [CrossRef] [PubMed]

5. Choudhry, H.; Harris, A.L. Advances in Hypoxia-Inducible Factor Biology. Cell Metab. 2018, 27, 281-298. [CrossRef]

6. van Uden, P.; Kenneth, N.S.; Rocha, S. Regulation of hypoxia-inducible factor-1alpha by NF-kappaB. Biochem. J. 2008, 412, 477-484. [CrossRef]

7. Bertoli, C.; Skotheim, J.M.; de Bruin, R.A.M. Control of cell cycle transcription during G1 and S phases. Nat. Rev. Mol. Cell Biol. 2013, 14, 518-528. [CrossRef]

8. Uchida, C. The retinoblastoma protein: Functions beyond the G1-S regulator. Curr. Drug Targets 2012, 13, 1622-1632. [CrossRef] [PubMed]

9. Palmer, N.; Kaldis, P. Less-well known functions of cyclin/CDK complexes. Semin Cell Dev. Biol. 2020, 107, 54-62. [CrossRef]

10. Lim, S.H.; Kaldis, P. Cdks, cyclins and CKIs: Roles beyond cell cycle regulation. Development 2013, 140, 3079-3093. [CrossRef]

11. Dang, F.; Nie, L.; Wei, W. Ubiquitin signaling in cell cycle control and tumorigenesis. Cell Death Differ. 2021, 28, 427-438. [CrossRef]

12. Malumbres, M.; Barbacid, M. Cell cycle, CDKs and cancer: A changing paradigm. Nat. Rev. Cancer 2009, 9, 153-166. [CrossRef] [PubMed]

13. Otto, T.; Sicinski, P. Cell cycle proteins as promising targets in cancer therapy. Nat. Rev. Cancer 2017, 17, 93-115. [CrossRef] [PubMed]

14. Ortmann, B.; Druker, J.; Rocha, S. Cell cycle progression in response to oxygen levels. Cell Mol. Life Sci. 2014, 71, 3569-3582. [CrossRef] [PubMed]

15. Koshiji, M.; Kageyama, Y.; Pete, E.A.; Horikawa, I.; Barrett, J.C.; Huang, L.E. HIF-1alpha induces cell cycle arrest by functionally counteracting Myc. EMBO J. 2004, 23, 1949-1956. [CrossRef] [PubMed]

16. Hackenbeck, T.; Knaup, K.X.; Schietke, R.; Schodel, J.; Willam, C.; Wu, X.; Warnecke, C.; Eckardt, K.U.; Wiesener, M.S. HIF-1 or HIF-2 induction is sufficient to achieve cell cycle arrest in NIH3T3 mouse fibroblasts independent from hypoxia. Cell Cycle 2009, 8, 1386-1395. [CrossRef] [PubMed]

17. Hubbi, M.E.; Semenza, G.L. Regulation of cell proliferation by hypoxia-inducible factors. Am. J. Physiol. Cell Physiol. 2015, 309, C775-C782. [CrossRef]

18. Garcia-Gutierrez, L.; Delgado, M.D.; Leon, J. MYC Oncogene Contributions to Release of Cell Cycle Brakes. Genes 2019, 10, 244 [CrossRef]

19. Gordan, J.D.; Bertout, J.A.; Hu, C.J.; Diehl, J.A.; Simon, M.C. HIF-2alpha promotes hypoxic cell proliferation by enhancing c-myc transcriptional activity. Cancer Cell 2007, 11, 335-347. [CrossRef]

20. Schodel, J.; Bardella, C.; Sciesielski, L.K.; Brown, J.M.; Pugh, C.W.; Buckle, V.; Tomlinson, I.P.; Ratcliffe, P.J.; Mole, D.R. Common genetic variants at the 11q13.3 renal cancer susceptibility locus influence binding of HIF to an enhancer of cyclin D1 expression. Nat. Genet. 2012, 44, 420-425, S421-422. [CrossRef] [PubMed]

21. Chen, W.; Hill, H.; Christie, A.; Kim, M.S.; Holloman, E.; Pavia-Jimenez, A.; Homayoun, F.; Ma, Y.; Patel, N.; Yell, P.; et al. Targeting renal cell carcinoma with a HIF-2 antagonist. Nature 2016, 539, 112-117. [CrossRef] [PubMed]

22. Cho, H.; Du, X.; Rizzi, J.P.; Liberzon, E.; Chakraborty, A.A.; Gao, W.; Carvo, I.; Signoretti, S.; Bruick, R.K.; Josey, J.A.; et al On-target efficacy of a HIF-2alpha antagonist in preclinical kidney cancer models. Nature 2016, 539, 107-111. [CrossRef] [PubMed]

23. Tang, A.; Gao, K.; Chu, L.; Zhang, R.; Yang, J.; Zheng, J. Aurora kinases: Novel therapy targets in cancers. Oncotarget 2017, 8, 23937-23954. [CrossRef] 
24. Meraldi, P.; Honda, R.; Nigg, E.A. Aurora-A overexpression reveals tetraploidization as a major route to centrosome amplification in p53-/- cells. EMBO J. 2002, 21, 483-492. [CrossRef]

25. Tatsuka, M.; Sato, S.; Kanda, A.; Miki, T.; Kamata, N.; Kitajima, S.; Kudo, Y.; Takata, T. Oncogenic role of nuclear accumulated Aurora-A. Mol. Carcinog 2009, 48, 810-820. [CrossRef] [PubMed]

26. Jeng, Y.M.; Peng, S.Y.; Lin, C.Y.; Hsu, H.C. Overexpression and amplification of Aurora-A in hepatocellular carcinoma. Clin. Cancer Res. 2004, 10, 2065-2071. [CrossRef] [PubMed]

27. Klein, A.; Flugel, D.; Kietzmann, T. Transcriptional regulation of serine/threonine kinase-15 (STK15) expression by hypoxia and HIF-1. Mol. Biol. Cell 2008, 19, 3667-3675. [CrossRef] [PubMed]

28. Fanale, D.; Bazan, V.; Corsini, L.R.; Caruso, S.; Insalaco, L.; Castiglia, M.; Cicero, G.; Bronte, G.; Russo, A. HIF-1 is involved in the negative regulation of AURKA expression in breast cancer cell lines under hypoxic conditions. Breast Cancer Res. Treat. 2013, 140, 505-517. [CrossRef]

29. Zhang, Y.; Cheng, Y.; Zhang, Z.; Bai, Z.; Jin, H.; Guo, X.; Huang, X.; Li, M.; Wang, M.; Shu, X.S.; et al. CDCA2 Inhibits Apoptosis and Promotes Cell Proliferation in Prostate Cancer and Is Directly Regulated by HIF-1alpha Pathway. Front. Oncol. 2020, 10, 725 [CrossRef]

30. Choudhry, H.; Harris, A.L.; McIntyre, A. The tumour hypoxia induced non-coding transcriptome. Mol. Asp. Med. 2016, 47-48, 35-53. [CrossRef]

31. Ledoux, A.C.; Perkins, N.D. NF-kappaB and the cell cycle. Biochem. Soc. Trans. 2014, 42, 76-81. [CrossRef] [PubMed]

32. Cummins, E.P.; Berra, E.; Comerford, K.M.; Ginouves, A.; Fitzgerald, K.T.; Seeballuck, F.; Godson, C.; Nielsen, J.E.; Moynagh, P.; Pouyssegur, J.; et al. Prolyl hydroxylase-1 negatively regulates IkappaB kinase-beta, giving insight into hypoxia-induced NFkappaB activity. Proc. Natl. Acad. Sci. USA 2006, 103, 18154-18159. [CrossRef]

33. Scholz, C.C.; Cavadas, M.A.; Tambuwala, M.M.; Hams, E.; Rodriguez, J.; von Kriegsheim, A.; Cotter, P.; Bruning, U.; Fallon, P.G.; Cheong, A.; et al. Regulation of IL-1beta-induced NF-kappaB by hydroxylases links key hypoxic and inflammatory signaling pathways. Proc. Natl. Acad. Sci. USA 2013, 110, 18490-18495. [CrossRef] [PubMed]

34. Cockman, M.E.; Lancaster, D.E.; Stolze, I.P.; Hewitson, K.S.; McDonough, M.A.; Coleman, M.L.; Coles, C.H.; Yu, X.; Hay, R.T.; Ley, S.C.; et al. Posttranslational hydroxylation of ankyrin repeats in IkappaB proteins by the hypoxia-inducible factor (HIF) asparaginyl hydroxylase, factor inhibiting HIF (FIH). Proc. Natl. Acad. Sci. USA 2006, 103, 14767-14772. [CrossRef] [PubMed]

35. Culver, C.; Sundqvist, A.; Mudie, S.; Melvin, A.; Xirodimas, D.; Rocha, S. Mechanism of hypoxia-induced NF-kappaB. Mol. Cell Biol. 2010, 30, 4901-4921. [CrossRef] [PubMed]

36. Melvin, A.; Mudie, S.; Rocha, S. Further insights into the mechanism of hypoxia-induced NFkappaB. [corrected]. Cell Cycle 2011, 10, 879-882. [CrossRef]

37. Bandarra, D.; Biddlestone, J.; Mudie, S.; Muller, H.A.; Rocha, S. Hypoxia activates IKK-NF-kappaB and the immune response in Drosophila melanogaster. Biosci. Rep. 2014, 34. [CrossRef]

38. Guttridge, D.C.; Albanese, C.; Reuther, J.Y.; Pestell, R.G.; Baldwin, A.S., Jr. NF-kappaB controls cell growth and differentiation through transcriptional regulation of cyclin D1. Mol. Cell Biol. 1999, 19, 5785-5799. [CrossRef]

39. Joyce, D.; Albanese, C.; Steer, J.; Fu, M.; Bouzahzah, B.; Pestell, R.G. NF-kappaB and cell-cycle regulation: The cyclin connection. Cytokine Growth Factor Rev. 2001, 12, 73-90. [CrossRef]

40. Sheehy, A.M.; Schlissel, M.S. Overexpression of RelA causes G1 arrest and apoptosis in a pro-B cell line. J. Biol. Chem. 1999, 274, 8708-8716. [CrossRef]

41. Bash, J.; Zong, W.X.; Gelinas, C. c-Rel arrests the proliferation of HeLa cells and affects critical regulators of the G1/S-phase transition. Mol. Cell Biol. 1997, 17, 6526-6536. [CrossRef] [PubMed]

42. Yamada, K.; Ono, M.; Perkins, N.D.; Rocha, S.; Lamond, A.I. Identification and functional characterization of FMN2, a regulator of the cyclin-dependent kinase inhibitor p21. Mol. Cell 2013, 49, 922-933. [CrossRef] [PubMed]

43. Fitzpatrick, S.F.; Tambuwala, M.M.; Bruning, U.; Schaible, B.; Scholz, C.C.; Byrne, A.; O'Connor, A.; Gallagher, W.M.; Lenihan, C.R.; Garvey, J.F.; et al. An intact canonical NF-kappaB pathway is required for inflammatory gene expression in response to hypoxia. J. Immunol. 2011, 186, 1091-1096. [CrossRef] [PubMed]

44. Bandarra, D.; Biddlestone, J.; Mudie, S.; Muller, H.A.; Rocha, S. HIF-1alpha restricts NF-kappaB-dependent gene expression to control innate immunity signals. Dis. Model. Mech. 2015, 8, 169-181. [CrossRef] [PubMed]

45. Araki, K.; Kawauchi, K.; Tanaka, N. IKK/NF-kappaB signaling pathway inhibits cell-cycle progression by a novel Rb-independent suppression system for E2F transcription factors. Oncogene 2008, 27, 5696-5705. [CrossRef] [PubMed]

46. Ankers, J.M.; Awais, R.; Jones, N.A.; Boyd, J.; Ryan, S.; Adamson, A.D.; Harper, C.V.; Bridge, L.; Spiller, D.G.; Jackson, D.A.; et al. Dynamic NF-kappaB and E2F interactions control the priority and timing of inflammatory signalling and cell proliferation. Elife 2016, 5. [CrossRef]

47. Costa, A.; Hood, I.V.; Berger, J.M. Mechanisms for initiating cellular DNA replication. Annu. Rev. Biochem. 2013, 82, 25-54. [CrossRef]

48. Saha, P.; Chen, J.; Thome, K.C.; Lawlis, S.J.; Hou, Z.-h.; Hendricks, M.; Parvin, J.D.; Dutta, A. Human CDC6/Cdc18 associates with Orc1 and cyclin-cdk and is selectively eliminated from the nucleus at the onset of S phase. Mol. Cell. Biol. 1998, 18, $2758-2767$. [CrossRef]

49. Lei, M.; Kawasaki, Y.; Young, M.R.; Kihara, M.; Sugino, A.; Tye, B.K. Mcm2 is a target of regulation by Cdc7-Dbf4 during the initiation of DNA synthesis. Genes Dev. 1997, 11, 3365-3374. [CrossRef] 
50. Hubbi, M.E.; Luo, W.; Baek, J.H.; Semenza, G.L. MCM proteins are negative regulators of hypoxia-inducible factor 1. Mol. Cell 2011, 42, 700-712. [CrossRef]

51. Hubbi, M.E.; Gilkes, D.M.; Rey, S.; Wong, C.C.; Luo, W.; Kim, D.-H.; Dang, C.V.; Levchenko, A.; Semenza, G.L. A nontranscriptional role for HIF-1 $\alpha$ as a direct inhibitor of DNA replication. Sci. Signal. 2013, 6, ra10. [CrossRef] [PubMed]

52. Takubo, K.; Goda, N.; Yamada, W.; Iriuchishima, H.; Ikeda, E.; Kubota, Y.; Shima, H.; Johnson, R.S.; Hirao, A.; Suematsu, M. Regulation of the HIF-1 $\alpha$ level is essential for hematopoietic stem cells. Cell Stem Cell 2010, 7, 391-402. [CrossRef] [PubMed]

53. Goda, N.; Ryan, H.E.; Khadivi, B.; McNulty, W.; Rickert, R.C.; Johnson, R.S. Hypoxia-inducible factor $1 \alpha$ is essential for cell cycle arrest during hypoxia. Mol. Cell. Biol. 2003, 23, 359-369. [CrossRef]

54. Gatenby, R.A.; Smallbone, K.; Maini, P.K.; Rose, F.; Averill, J.; Nagle, R.B.; Worrall, L.; Gillies, R.J. Cellular adaptations to hypoxia and acidosis during somatic evolution of breast cancer. Br. J. Cancer 2007, 97, 646-653. [CrossRef] [PubMed]

55. Epstein, A.C.; Gleadle, J.M.; McNeill, L.A.; Hewitson, K.S.; O’Rourke, J.; Mole, D.R.; Mukherji, M.; Metzen, E.; Wilson, M.I.; Dhanda, A.; et al. C. elegans EGL-9 and mammalian homologs define a family of dioxygenases that regulate HIF by prolyl hydroxylation. Cell 2001, 107, 43-54. [CrossRef]

56. Fandrey, J.; Gorr, T.A.; Gassmann, M. Regulating cellular oxygen sensing by hydroxylation. Cardiovasc. Res. 2006, 71, 642-651. [CrossRef]

57. Briggs, K.J.; Koivunen, P.; Cao, S.; Backus, K.M.; Olenchock, B.A.; Patel, H.; Zhang, Q.; Signoretti, S.; Gerfen, G.J.; Richardson, A.L.; et al. Paracrine Induction of HIF by Glutamate in Breast Cancer: EglN1 Senses Cysteine. Cell 2016, 166, 126-139. [CrossRef]

58. Duran, R.V.; MacKenzie, E.D.; Boulahbel, H.; Frezza, C.; Heiserich, L.; Tardito, S.; Bussolati, O.; Rocha, S.; Hall, M.N.; Gottlieb, E. HIF-independent role of prolyl hydroxylases in the cellular response to amino acids. Oncogene 2013, 32, 4549-4556. [CrossRef]

59. Kaelin, W.G., Jr. Cancer and altered metabolism: Potential importance of hypoxia-inducible factor and 2-oxoglutarate-dependent dioxygenases. Cold Spring Harb. Symp. Quant. Biol. 2011, 76, 335-345. [CrossRef]

60. Bailey, P.S.J.; Nathan, J.A. Metabolic Regulation of Hypoxia-Inducible Transcription Factors: The Role of Small Molecule Metabolites and Iron. Biomedicines 2018, 6, 60. [CrossRef]

61. Cockman, M.E.; Lippl, K.; Tian, Y.M.; Pegg, H.B.; Figg, W.D.J.; Abboud, M.I.; Heilig, R.; Fischer, R.; Myllyharju, J.; Schofield, C.J.; et al. Lack of activity of recombinant HIF prolyl hydroxylases (PHDs) on reported non-HIF substrates. Elife 2019, 8. [CrossRef]

62. Bersten, D.C.; Peet, D.J. When is a target not a target? Elife 2019, 8. [CrossRef] [PubMed]

63. Moser, S.C.; Bensaddek, D.; Ortmann, B.; Maure, J.-F.; Mudie, S.; Blow, J.J.; Lamond, A.I.; Swedlow, J.R.; Rocha, S. PHD1 Links Cell-Cycle Progression to Oxygen Sensing through Hydroxylation of the Centrosomal Protein Cep192. Dev. Cell 2013, 26, 381-392. [CrossRef]

64. Xie, L.; Pi, X.; Mishra, A.; Fong, G.; Peng, J.; Patterson, C. PHD3-dependent hydroxylation of HCLK2 promotes the DNA damage response. J. Clin. Investig. 2012, 122, 2827-2836. [CrossRef]

65. Gomez-Ferreria, M.A.; Rath, U.; Buster, D.W.; Chanda, S.K.; Caldwell, J.S.; Rines, D.R.; Sharp, D.J. Human Cep192 is required for mitotic centrosome and spindle assembly. Curr. Biol. 2007, 17, 1960-1966. [CrossRef] [PubMed]

66. Sonnen, K.F.; Gabryjonczyk, A.M.; Anselm, E.; Stierhof, Y.D.; Nigg, E.A. Human Cep192 and Cep152 cooperate in Plk4 recruitment and centriole duplication. J. Cell Sci. 2013, 126, 3223-3233. [CrossRef]

67. Zhu, F.; Lawo, S.; Bird, A.; Pinchev, D.; Ralph, A.; Richter, C.; Muller-Reichert, T.; Kittler, R.; Hyman, A.A.; Pelletier, L. The mammalian SPD-2 ortholog Cep192 regulates centrosome biogenesis. Curr. Biol. 2008, 18, 136-141. [CrossRef]

68. Zheng, X.; Zhai, B.; Koivunen, P.; Shin, S.J.; Lu, G.; Liu, J.; Geisen, C.; Chakraborty, A.A.; Moslehi, J.J.; Smalley, D.M.; et al. Prolyl hydroxylation by EgIN2 destabilizes FOXO3a by blocking its interaction with the USP9x deubiquitinase. Genes Dev. 2014, 28, 1429-1444. [CrossRef] [PubMed]

69. Zhang, Q.; Gu, J.; Li, L.; Liu, J.; Luo, B.; Cheung, H.W.; Boehm, J.S.; Ni, M.; Geisen, C.; Root, D.E.; et al. Control of cyclin D1 and breast tumorigenesis by the EglN2 prolyl hydroxylase. Cancer Cell 2009, 16, 413-424. [CrossRef]

70. Percy, M.J.; Zhao, Q.; Flores, A.; Harrison, C.; Lappin, T.R.; Maxwell, P.H.; McMullin, M.F.; Lee, F.S. A family with erythrocytosis establishes a role for prolyl hydroxylase domain protein 2 in oxygen homeostasis. Proc. Natl. Acad. Sci. USA 2006, 103, 654-659. [CrossRef]

71. Tao, Y.; Lin, F.; Li, R.; Shen, J.; Wang, Z. Prolyl hydroxylase-2 inhibits liver tumor cell proliferation and cyclin D1 expression in a hydroxylase-dependent manner. Int. J. Biochem. Cell Biol. 2016, 77, 129-140. [CrossRef]

72. Erez, N.; Milyavsky, M.; Eilam, R.; Shats, I.; Goldfinger, N.; Rotter, V. Expression of prolyl-hydroxylase-1 (PHD1/EGLN2) suppresses hypoxia inducible factor-1alpha activation and inhibits tumor growth. Cancer Res. 2003, 63, 8777-8783. [PubMed]

73. Jokilehto, T.; Jaakkola, P.M. The role of HIF prolyl hydroxylases in tumour growth. J. Cell Mol. Med. 2010, 14, 758-770. [CrossRef]

74. Wottawa, M.; Leisering, P.; Ahlen, M.; Schnelle, M.; Vogel, S.; Malz, C.; Bordoli, M.R.; Camenisch, G.; Hesse, A.; Napp, J.; et al. Knockdown of prolyl-4-hydroxylase domain 2 inhibits tumor growth of human breast cancer MDA-MB-231 cells by affecting TGF-beta1 processing. Int. J. Cancer 2013, 132, 2787-2798. [CrossRef] [PubMed]

75. Klotzsche-von Ameln, A.; Muschter, A.; Heimesaat, M.M.; Breier, G.; Wielockx, B. HIF prolyl hydroxylase-2 inhibition diminishes tumor growth through matrix metalloproteinase-induced TGFbeta activation. Cancer Biol. Ther. 2012, 13, 216-223. [CrossRef] [PubMed] 
76. Klotzsche-von Ameln, A.; Muschter, A.; Mamlouk, S.; Kalucka, J.; Prade, I.; Franke, K.; Rezaei, M.; Poitz, D.M.; Breier, G.; Wielockx, B. Inhibition of HIF prolyl hydroxylase-2 blocks tumor growth in mice through the antiproliferative activity of TGFbeta. Cancer Res. 2011, 71, 3306-3316. [CrossRef]

77. Chen, S.; Zhang, J.; Li, X.; Luo, X.; Fang, J.; Chen, H. The expression of prolyl hydroxylase domain enzymes are up-regulated and negatively correlated with Bcl-2 in non-small cell lung cancer. Mol. Cell Biochem. 2011, 358, 257-263. [CrossRef] [PubMed]

78. Su, Y.; Loos, M.; Giese, N.; Hines, O.J.; Diebold, I.; Gorlach, A.; Metzen, E.; Pastorekova, S.; Friess, H.; Buchler, P. PHD3 regulates differentiation, tumour growth and angiogenesis in pancreatic cancer. Br. J. Cancer 2010, 103, 1571-1579. [CrossRef]

79. Tennant, D.A.; Gottlieb, E. HIF prolyl hydroxylase-3 mediates alpha-ketoglutarate-induced apoptosis and tumor suppression. J. Mol. Med. 2010, 88, 839-849. [CrossRef]

80. Tang, L.R.; Wu, J.X.; Cai, S.L.; Huang, Y.X.; Zhang, X.Q.; Fu, W.K.; Zhuang, Q.Y.; Li, J.L. Prolyl hydroxylase domain 3 influences the radiotherapy efficacy of pancreatic cancer cells by targeting hypoxia-inducible factor-1alpha. Onco. Targets Ther. 2018, 11, 8507-8515. [CrossRef]

81. Chen, J. The Cell-Cycle Arrest and Apoptotic Functions of p53 in Tumor Initiation and Progression. Cold Spring Harb. Perspect Med. 2016, 6, a026104. [CrossRef] [PubMed]

82. Rodriguez, J.; Herrero, A.; Li, S.; Rauch, N.; Quintanilla, A.; Wynne, K.; Krstic, A.; Acosta, J.C.; Taylor, C.; Schlisio, S.; et al. PHD3 Regulates p53 Protein Stability by Hydroxylating Proline 359. Cell Rep. 2018, 24, 1316-1329. [CrossRef] [PubMed]

83. Frost, J.; Galdeano, C.; Soares, P.; Gadd, M.S.; Grzes, K.M.; Ellis, L.; Epemolu, O.; Shimamura, S.; Bantscheff, M.; Grandi, P.; et al Potent and selective chemical probe of hypoxic signalling downstream of HIF-alpha hydroxylation via VHL inhibition. Nat. Commun. 2016, 7, 13312. [CrossRef]

84. Testa, J.R.; Bellacosa, A. AKT plays a central role in tumorigenesis. Proc. Natl. Acad. Sci. USA 2001, 98, 10983-10985. [CrossRef] [PubMed]

85. Guo, J.; Chakraborty, A.A.; Liu, P.; Gan, W.; Zheng, X.; Inuzuka, H.; Wang, B.; Zhang, J.; Zhang, L.; Yuan, M.; et al. pVHL suppresses kinase activity of Akt in a proline-hydroxylation-dependent manner. Science 2016, 353, 929-932. [CrossRef]

86. Lee, S.B.; Ko, A.; Oh, Y.T.; Shi, P.; D’Angelo, F.; Frangaj, B.; Koller, A.; Chen, E.I.; Cardozo, T.; Iavarone, A.; et al. Proline Hydroxylation Primes Protein Kinases for Autophosphorylation and Activation. Mol. Cell 2020, 79, 376-389.e8. [CrossRef] [PubMed]

87. Lee, S.B.; Frattini, V.; Bansal, M.; Castano, A.M.; Sherman, D.; Hutchinson, K.; Bruce, J.N.; Califano, A.; Liu, G.; Cardozo, T.; et al. An ID2-dependent mechanism for VHL inactivation in cancer. Nature 2016, 529, 172-177. [CrossRef] [PubMed]

88. Aranda, S.; Laguna, A.; de la Luna, S. DYRK family of protein kinases: Evolutionary relationships, biochemical properties, and functional roles. FASEB J. 2011, 25, 449-462. [CrossRef]

89. Albanese, A.; Daly, L.A.; Mennerich, D.; Kietzmann, T.; See, V. The Role of Hypoxia-Inducible Factor Post-Translational Modifications in Regulating Its Localisation, Stability, and Activity. Int. J. Mol. Sci. 2020, 22, 268. [CrossRef]

90. Warfel, N.A.; Dolloff, N.G.; Dicker, D.T.; Malysz, J.; El-Deiry, W.S. CDK1 stabilizes HIF-1alpha via direct phosphorylation of Ser668 to promote tumor growth. Cell Cycle 2013, 12, 3689-3701. [CrossRef]

91. Hubbi, M.E.; Gilkes, D.M.; Hu, H.; Kshitiz; Ahmed, I.; Semenza, G.L. Cyclin-dependent kinases regulate lysosomal degradation of hypoxia-inducible factor $1 \alpha$ to promote cell-cycle progression. Proc. Natl. Acad. Sci. USA 2014, 111, E3325-E3334. [CrossRef]

92. Biswas, K.; Sarkar, S.; Said, N.; Brautigan, D.L.; Larner, J.M. Aurora B Kinase Promotes CHIP-Dependent Degradation of HIF1alpha in Prostate Cancer Cells. Mol. Cancer Ther. 2020, 19, 1008-1017. [CrossRef]

93. Xu, D.; Yao, Y.; Lu, L.; Costa, M.; Dai, W. Plk3 functions as an essential component of the hypoxia regulatory pathway by direct phosphorylation of HIF-1alpha. J. Biol. Chem. 2010, 285, 38944-38950. [CrossRef]

94. Ortmann, B.; Bensaddek, D.; Carvalhal, S.; Moser, S.C.; Mudie, S.; Griffis, E.R.; Swedlow, J.R.; Lamond, A.I.; Rocha, S. CDKdependent phosphorylation of PHD1 on serine 130 alters its substrate preference in cells. J. Cell Sci. 2016, 129, 191-205. [CrossRef] [PubMed]

95. Matsumura, I.; Tanaka, H.; Kanakura, Y. E2F1 and c-Myc in cell growth and death. Cell Cycle 2003, 2, 333-338. [CrossRef] [PubMed]

96. Obaya, A.J.; Kotenko, I.; Cole, M.D.; Sedivy, J.M. The proto-oncogene c-myc acts through the cyclin-dependent kinase (Cdk) inhibitor p27(Kip1) to facilitate the activation of Cdk4/6 and early G(1) phase progression. J. Biol. Chem. 2002, 277, 31263-31269. [CrossRef]

97. Oh, E.T.; Kim, J.W.; Kim, J.M.; Kim, S.J.; Lee, J.S.; Hong, S.S.; Goodwin, J.; Ruthenborg, R.J.; Jung, M.G.; Lee, H.J.; et al. NQO1 inhibits proteasome-mediated degradation of HIF-1alpha. Nat. Commun. 2016, 7, 13593. [CrossRef] [PubMed]

98. Sabapathy, K.; Wagner, E.F. JNK2: A negative regulator of cellular proliferation. Cell Cycle 2004, 3, 1520-1523. [CrossRef] [PubMed]

99. Di Conza, G.; Trusso Cafarello, S.; Loroch, S.; Mennerich, D.; Deschoemaeker, S.; Di Matteo, M.; Ehling, M.; Gevaert, K.; Prenen, H.; Zahedi, R.P.; et al. The mTOR and PP2A Pathways Regulate PHD2 Phosphorylation to Fine-Tune HIF1alpha Levels and Colorectal Cancer Cell Survival under Hypoxia. Cell Rep. 2017, 18, 1699-1712. [CrossRef]

100. Shi, M.; Dai, W.Q.; Jia, R.R.; Zhang, Q.H.; Wei, J.; Wang, Y.G.; Xiang, S.H.; Liu, B.; Xu, L. APC(CDC20)-mediated degradation of PHD3 stabilizes HIF-1a and promotes tumorigenesis in hepatocellular carcinoma. Cancer Lett. 2021, 496, 144-155. [CrossRef] 